University of Warwick institutional repository: http://go.warwick.ac.uk/wrap This paper is made available online in accordance with publisher policies. Please scroll down to view the document itself. Please refer to the repository record for this item and our policy information available from the repository home page for further information.

To see the final version of this paper please visit the publisher's website. Access to the published version may require a subscription.

Author(s): Ben Clift

Article Title: The Ségolène Royal Phenomenon: Political Renewal in France?

Year of publication: 2007

Link to published version:

http://dx.doi.org/10.1111/j.1467-923X.2007.00855.x

Publisher statement: The definitive version is available at www.blackwell-synergy.com 


\section{The Ségolène Royal Phenomenon: Political Renewal in France?}

\section{BEN CLIFT}

Ségolène Royal's meteoric rise during 2006 to become the first ever female mainstream presidential candidate in France augured a turning point for the French left, not only because of her gender, but also because of her challenge to the left's traditional organisational and ideological norms of presidential electoral politics. Presentationally, Royal successfully reinvented herself as an outsider to the French political elite, seeking to engage citizens with politics in novel ways, and articulating her politics in a different language. Yet paradoxically, a cursory look at her CV indicates that she is a chip off the old Socialist block. A former Mitterrand adviser, her campaign is co-directed by Jean-Louis Bianco, Mitterrand's Elysée chief of staff between 1982 and 1991. She is a graduate of ENA, where she met François Hollande (Jospin's dauphin and First Secretary of the French Socialist Party since 1997), with whom she has four children. A Socialist parliamentarian since 1988, and minister between 1992-3 and 1997-2002, Royal was elected Socialist president of the PoitouCharentes region in 2004.

This apparent inconsistency was overlooked because of her strong opinion poll ratings, the ultimate arbitrator of each candidate's credibility within the unprecedented November 2006 parti socialiste (PS) primary contest. Royal's massive advantage in popularity throughout 2006 proved decisive. In September, 46 per cent of respondents said that they would probably vote for her in the 2007 presidential election, compared to 49 per cent for Nicolas Sarkozy; the next nearest left candidate was Lionel Jospin (who subsequently withdrew) on 27 per cent. Her eventual competitors in the primary, Strauss-Kahn and Fabius, were languishing behind with 18 and 13 per cent respectively. ${ }^{1}$

Students of French electoral politics distinguish between the 'useful' vote (for the candidate most likely to win) and the 'strategic' vote (for the candidate with whose ideas you have most affinity). In dual-ballot elections, there is often a division of labour - with the 'strategic' vote prevailing in the first round and the 'useful' voting kicking in for the second. In the recent PS primary, it seems that the 'useful' vote operated on a large scale from the first round, with Royal's success rooted in the 
judgement that she had the best chance of defeating Sarkozy at the presidential electoral showdown in April/May 2007. The scale of her success (securing over 60 per cent of the vote, with her rivals both around 20 per cent) was all the more remarkable given that her campaign promised a decisive break with the party's past, both organisationally and ideologically.

\section{The paradox of presidentialised parties}

De Gaulle’s linking of presidential electors to a parliamentary majority in his 1962 masterstroke was a watershed event in the Fifth Republic party system. Ever since, all French presidential candidates have needed critical distance from parties, and a distinctly personal dimension to their candidacy as well as a secure link to party resources, and partisan coalition-constructing potential. The advent of the 'presidential majority’ precipitated the presidentialisation of internal party power relations, creating 'presidential parties', with shared attributes arising from the structural influences of the semi-presidential Fifth Republic. Thereafter, a new French constitutional convention, 'the principle of presidential initiative', ${ }^{2}$ subordinated the party to president in policy formation, personnel selection, policy selection and electoral campaigning. Major French parties are today conceived as presidential machines, whose primary function is to act as a springboard for a presidential candidacy, and subsequently to act as an organisational resource for the president.

The symbiosis between party and candidate is a complex one, rooted in the competing logics underpinning the operation of the French party system. First de Gaulle on the right surreptitiously then Mitterrand on the left openly embraced the political resources (in terms of organisational strength, and an alternative source of political legitimacy) that parties could offer. Yet the personal character of elections endured, albeit framed in an explicit partisan context. After the 1960s, the organisational evolution of French parties was characterised by personalised leadership contingent upon power resources continually 'sourced by' opinion poll popularity. Mitterrand's presidentialisation of the parti socialiste (PS) after the 1971 Epinay conference completed the appropriation of the presidential election by the major parties in France.

The presidentialising tendencies within the French Fifth Republic were further enhanced by the constitutional reform in 2000 introducing the Quinquennat (the fiveyear presidential term). The aligning of the presidential and legislative terms greatly 
reduced the likelihood of 'cohabitation', effectively securing the presidential as opposed to parliamentary 'reading' of the 1958 Constitution. This was further underlined by the inversion of the electoral calendar (placing the presidential elections ahead of the parliamentary), ensuring that the composition of Parliament takes place in the light of the presidential election results.

Yet paradoxically, given that their raison d'être was rooted in the presidential election, all French parties failed to resolve the issue of how to select presidential candidates. Despite over four decades of presidentialised party politics, on left and right, all previous party attempts to monopolise presidential candidate selection were unsuccessful, and the absence of such a mainstream left pre-contest process of elimination in 2002 proved extremely costly. Candidates tended to 'emerge' much as leaders of the UK Conservative party used to, which led to enormous intra-party tensions between numerous pretenders to the throne when consensus was lacking over who the next presidential candidate should be, notably in the PS after 1988 and 2002. The recent codified, orderly internal primaries within the PS, complete with a series of televised debates, suggests that the PS may have overcome this perennial problem. On the right, the UMP's planned emulation of the PS primary in early 2007 became, in effect, a coronation of the irrepressible Sarkozy.

However, these were uncharted waters for the PS, and the late November completion meant a very long campaign ahead. This left plenty of time for party infighting to break out. Such dissent was all the more likely with Ségolène Royale going out of her way to annoy the PS old guard in her treatment of the party. Would all the courants (party factions) and all the éléphants (senior members of the party elite), including those licking the wounds of their bruising defeat, behave themselves? A crucial precondition of quiescence in 2006, it turned out, was strong opinion polling for the PS présidentiable. As her scores dipped in early 2007, the 'noises off' began to make themselves heard.

\section{Ségolène Royal and the PS: organisational renewal?}

Previous candidacies have been rooted in the peculiar norms of party organisation within the PS, and the disparity between official and actual authority structures. Prevailing presidential candidates normally construct the embryo of a ligne majoritaire, or internal governing coalition, in relation to the established courants or ideological tendencies within the party. This coalition-building process has tended to 
embrace a Gramscian understanding of hegemony as a combination of force and consent, making concessions to weaker groups to secure acquiescence (offering side payments in terms of place on the party's governing bodies), whilst couching the rhetoric of leadership in universalistic terms of a general interest. First Mitterrand and then Jospin institutionalised their ascendancy within the party in this way.

The advantage of the ligne majoritaire is to change the nature of the French Socialist's presidentialised factionalism, underpinned by internal proportional representation. Thus Mitterrand acquired 'leader above faction' status, with all the competing factions synthesising their positions, creating one single de facto faction, with Mitterrand as first signatory, making him internal kingmaker par excellence. A similar internal configuration obtained between 1995 and 2002 during Jospin’s unquestioned présidentiable and internally hegemonic phase, reinforced by a newly instated one-member, one-vote leadership election. The ascendancy of Jospin's dauphin François Hollande in 1997 was exactly the kind of formality that the ‘presidential party' model would predict.

Throughout 2006, both organisationally and ideologically, Ségolène Royal fastidiously neglected to build such a coalition, and pointedly did not reach out to her defeated heavyweight adversaries in the PS primary, Dominic Strauss-Kahn and Laurent Fabius. The genesis of Ségolène Royal's candidacy was thus unusual for the French left in her relationship to the PS as 'presidential party'. Her campaign began in early 2006 with the establishment of her own political organisation, Désirs d'Avenir. A crucial means of her building up support, this quasi-party advocated participatory democratic involvement in the campaign on the Internet (where, she said, 50 per cent of her campaign would take place!), through blogs and web chats. Royal wanted to tap into the 'collective intelligence' of the French nation, inviting policy submissions on her website's message-boards (she received over 135,000). Désirs d'Avenir thus reached out beyond the socialist camp, to the wider French electorate. Her quasioutsider candidacy has some historical resonance with Mitterrand’s 1965 campaign when, relying on his presidential qualities and Fourth Republic governmental credentials, he 'informed' the parties of the left of his decision to stand for president and demanded that they align themselves accordingly behind him.

François Hollande chose another historical reference, Mitterrand's 1981 campaign; 'the candidate has their own team, but the strategic definition of the campaign should be done around the PS, with the party fully implicated in the process 
of uniting the Left'. Many regard party organisational resources as indispensable to a successful candidacy. Mitterrand's loose confederation in 1965, for example, provided woefully inadequate party resources compared with de Gaulle’s well-oiled Union pour la Nouvelle République machine. Hollande concurs, noting that 'the party is a major force which no-one can do without'. ${ }^{3}$ On her inauguration, it seemed that Royal did not agree with her partner on this point. Royal, throughout 2006, circumvented official party authority structures. Whilst she did symbolically choose party headquarters for her campaign headquarters, and invited one or two of Mitterrand's old guard into her inner circle, she was unconcerned with keeping the contemporary courants 'on board'. Many senior figures in her initial campaign were outsiders, and both the Strauss-Kahn and Fabius factions were conspicuous by their absence. Despite her official campaign base at Socialist party headquarters, it became clear as the campaign progressed that her real campaign nerve centre was round the corner at 282 Boulevard St-Germain (which was an éléphant-free zone).

In late 2006, traditional internal party politicking was overshadowed by the primary result. Regardless of her ambiguous position in relation to the party's factions, and indeed the party hierarchy, Ségolène Royale was incontournable (unbypassable). By endorsing her so decisively with 60 per cent of the internal vote, the PS effectively signed a blank cheque, committing itself to support her throughout the presidential campaign, whatever its focus, tone and character. Royal's strategic calculation was that the party had nowhere else to go, and would have to keep supporting her, certainly as long as her presidential credentials were reaffirmed in the incessant poll ratings.

Ségolène Royal set out in her investiture speech a vision of a campaign that held no particular place for the party, or even socialist sympathisers; 'now that the socialists have done a lot of talking amongst themselves, we are going to turn ourselves towards the French people'. Thus, as soon as her success in the primaries was secured, there was to be no special role for the party within the campaign. Rather, she charted a 'listening phase' of her campaign until the end of January 2007, promising to tour the land meeting French citizens and finding out from them what they want to be in her programme. Many of the themes and slogans of her primary campaign remained very vague, and she has justified this by claiming that it was up to the French people to clarify the meaning in these terms. By the end of the national 
listening tour, she would 'find the right words, and put forward the right proposals which resonate profoundly' with the French people. ${ }^{4}$

Royal seeks to embody a sense of political renewal in France, and rather grandly characterises her project as a 'democratic revolution'. Not unreasonably, she draws attention to her gender to underline her novelty and the sense that her candidacy represents a break with France's political traditions. Ségolène Royal is the first ever female mainstream, electable candidate for the French presidency. She accused Strauss-Kahn and Fabius of male chauvinism during the primary campaign, attributing to them dismissive sexist remarks about her candidacy, notably 'but who will look after the children?' Royal made political capital out of this, presenting herself as an outsider, changing the way politics is done and spoken about, and tackling issues on which the patriarchal French state has too long been silent. Thus she proclaimed, 'I came to Socialism through feminism, and through revulsion at the subordination of women.' She deemed her candidacy 'a revolutionary gesture, ${ }^{5}$ evoking the legacy of French feminism's heroine of the revolution, Olympe de Gouges (whose body will be transferred to the Panthéon if Royal wins). Her very first law if elected president, she has pledged, will tackle violence towards women in the home.

The sense of renewal also relates to both the form and content of her politics. Hers is a new political style, placing great emphasis on participatory democracy as both a theme of her political agenda and a mode of campaigning. In terms of her agenda, she advocates constitutional reforms empowering Parliament, as well as further decentralisation in a bid to improve accountability and bring the exercise of politics closer to the people. She has also controversially called for the convening of 'citizen's juries' to hold elected politicians to account. As regards her campaign, the 'listening phase' and the reliance on her Désirs d'Avenir organisation encouraging everyone's political engagement through the Internet embody her participatory spirit. She sought a 'participatory debate,' through meetings with elected officials at every level, as well as ordinary citizens. Such grass-roots politics, Royal claimed, were integral to her campaign and its themes. The unorthodoxy, some would say populism, of this campaigning style ruffled the feathers of the party hierarchy. Furthermore, it highlights the second major dimension of the distinctiveness of the Royal candidacy - the degree to which it departs from French Socialist ideological traditions, and the habitual norms of political discourse in France. 


\section{Ségolène Royal and French socialism: ideological renewal?}

Perhaps the most striking innovation is Ségolène Royal's positioning in relation to the party's cherished ideological traditions. Unusually for a socialist politician, she rarely refers to the great Socialist thinkers of the twentieth century, such as Jean Jaurès or Léon Blum. Indeed, Sarkozy mischievously highlighted this by himself evoking Jaurès in a campaign speech about employment. The PS is a party reverent of its intellectual heritage, and one in which ideological production, and rhetorical invocation of that ideological output, is a very significant feature of party life. Ideological discussion is normally handled with kid gloves by party members and elites alike. The PS is obsessed with its texts not only because such ideological traditions are testament to a valued legacy, but also because they form the currency of internal squabbling and power-brokering within the party. Each faction battles for 'their' key term, concept or policy to prevail. Every reference is pored over in the ideological battleground of the 'synthesis committee' at conference, which usually meets all night long in a bid to arrive at a final text that is agreeable to all factions within the new ligne majoritaire. Alongside seats on the party's governing bodies, the composition, precise wording and ideological tone of the synthesis is, for the knowing audience, the way to measure the relative strength of each faction within the party. Yet Ségolène Royal is talking an entirely different language to that which the PS has been speaking for decades.

At the risk of mild over-simplification, in the PS primary, the two dominant ideological traditions of the modern French Socialist Party were more or less explicitly represented by her adversaries, Strauss-Kahn and Fabius. Fabius represents the Mitterrandist traditional left 'première gauche'—republican, statist and committed to dirigiste intervention to deliver the ideal of equality. Strauss-Kahn represents the Rocardian modernising 'deuxième gauche', of the post-1968 French left. This less statist tradition was initially interested in ideas of ‘autogestion' (self-determination) and more recently has sought greater realism and pragmatism, and more accommodation with the market. The great ideological showdown between the two traditions was at the Metz conference of 1979, when Mitterrand, as the representative of the première gauche, defeated Rocard. In 2006, Ségolène Royal ran explicitly on a 'neither of the above' ticket, deliberately positioning herself outside the party's treasured intellectual referential. Indeed, she made political capital out of her 
antipathy towards the traditional mode of abstract political rhetoric in France, seeing it (probably rightly) as a source of abstentionism, aversion to politics and the mooted crisis of representation in France.

Rejecting this old style of political rhetoric as a vote-loser, Royal presents her own personal vision, couched in novel, down-to-earth terms. As François Hollande puts it, 'she has a language very different from that which has hitherto been used within our political life, she has a way of speaking about people's everyday problems, and a way of taking up positions on subjects which are normally outside our political discussions'. ${ }^{6}$ She assiduously established critical distance from the PS's Projet Socialiste, a document that the party intended as the cornerstone for the 2007 campaign. In her acceptance speech she made pointed reference to her intention to 'return the French people to the heart of the French Socialist Project', clearly implying that the people were not at the heart of the party's July 2006 text. In another coded jibe at the party's 'double discourse,' whereby rhetorical ideological flourishes encourage expectations that are not realised in office, Royal recorded her intention to 'bring some precisions, in order to say today what we will do tomorrow if the French people have confidence in me'. ${ }^{7}$ Not all agreed, on reading her Presidential Pact and hearing her speeches and positions in early 2007, that she had fully heeded her own advice.

Royal also established critical distance from aspects of the Jospin governmental legacy. She talks openly of the thirty-five hour week's 'perverse side effects', rather a taboo subject within the party. Royal's positioning owes much to a close reading of opinion polls: there is evidence from these to suggest that the thirtyfive hour week never fully met the aspirations its originators had for it. Whilst popular amongst cadres and middle-class voters, the lower-skilled target audience found their overtime curtailed, their take-home pay reduced and conditions at work worse. ${ }^{8}$ Thus her argument for 'assouplissement' or 'softening' on the thirty-five hour week is rooted both in electoral considerations, as well as a bid to establish distance from the PS.

Another telling facet of Royal ideologically is that she won the primary decisively without a programme. This was justified with reference to her participatory democratic agenda, whereby the final programme would emerge through consultations with the citizenry, and even ideas posted on her website. In lieu of a programme, Royal offered a number of slogans that purport to set out her core values. 
These include ordre juste ('just order'), désirs d'avenir ('aspirations for the future’), l'excellence environnementale ('environmental excellence'), tackling la vie chère ('the high cost of living') and république du respect ('a republic of respect'). Royal countered criticisms that these are empty, ambiguous phrases by claiming that they will acquire meaning and substance through a dialogue with the French people.

Perhaps because of this ideological fluidity, many have evoked a comparison with Blair, citing Royal's admiration of Blair, set out in a Financial Times interview in February 2006. There are certainly echoes of some 'Blairite' ideas within Royal's political project, such as emphasis on parental choice in schools, on education and training, on 'employability' and on obligations (to retrain) accompanying any benefits received. It is on law and order where the comparison is most apt. In its ambiguity, the core 'ordre juste' theme is akin to earlier French Socialist tenets, but it is highly innovative in the political terrain that it stakes out for the Royal campaign. The kind of authoritarian populist law and order stance combined with rhetorical commitments to social justice that have become part of the political furniture of the mainstream left in the UK under New Labour are anathema to much of the PS, and almost unheard of in France. One of Royal's more noteworthy policy ideas is the incarceration of juvenile delinquents in military boot camps. This was unprecedented terrain for the PS, turning up, in effect, to the right of Minister of the Interior Sarkozy on law and order. The contrast with 2002 is striking. Then, law and order was a key issue in the campaign where Le Pen and Chirac played well in the polls, but the decidedly unauthoritarian Jospin was at sea, and lost ground.

However, whilst the disaffected PS left are keen to share this analysis of a dangerous centrist drift within French socialism, the comparison with Blair is ultimately misleading. Ségolène Royal is a complex blend of diverse elements; indeed, perhaps her Achilles heel is that one cannot identify a consistent ideological core. Yet her political economic vision is clearly distinct from that of New Labour. For one thing, she stands for a renewed commitment to mass unionism in France as one means of achieving the participatory democracy to which she aspires. She repeatedly (and unrealistically) calls for mass re-unionisation as one solution to France's economic ills, to be achieved through 'modernised social dialogue' and an annual national wage-bargaining conference.

Secondly, Royal has not been prepared to compromise, rhetorically at least, on the issue of lifelong employment security, which she continues to characterise as a 
French social right. Hers is an understanding of the 'employability' agenda and activist labour market policies introduced into a much more regulated labour market context, securing much higher minimum standards in terms of pay and employment security than New Labour are prepared to countenance. Royal is committed to a substantial rise in the minimum wage. Her broader vision is for emulation not of Anglo-Saxon capitalism (as her defeated opponent Strauss-Kahn suggested), but the more egalitarian Nordic model of capitalism (albeit without emulating Nordic taxation levels). When asked about solutions to France's unemployment problem, she makes repeated references to the Swedish and Danish social models.

Thirdly, there is a consistent critique of untrammelled free markets, and liberal hyper-globalism. Her investiture speech talked of resisting 'the ill wind of rampant liberalism', and her stance on 'délocalisation' (outsourcing) recommends nationaland EU-level regulation restricting the practice, and withholding any public subsidy from any firm planning delocalisation whilst it is making a profit. She has made numerous ouvertures to the 'alter-mondialiste' movement in France (including offering an amnesty to anti-GM food protestors), within which the likes of José Bové campaign for a different kind of engagement with globalisation, regulated and contained by politics to ensure compatibility with the French social model.

Finally, the language used to frame her vision betrays how, in certain respects, Royal remains staunchly left. Alongside praise for the Nordic model is criticism of 'the capitalists'. As she told The Times in October 2006, 'the capitalists have to be frightened ... They can’t just dispose of people as they wish. They have to be held accountable.' She continued, 'we have to prevent this wildcat outsourcing ... The workers have no power. We need to tax businesses who want to move out jobs and tax their products when they re-import them. ${ }^{, 9}$ It is hard to conceive of Blair even characterising 'the capitalists' as capitalists, let alone suggesting that they need to be frightened.

\section{The troubled campaign}

Royal's initial campaign team reflected her critical distance from the party's hierarchy and traditions. One of her key spokespeople, Arnaud Montebourg, is one of the very few significant figures within the PS who is not definable in terms of the courants who have dominated the party since its inception. Montebourg was unusual at the 2005 Mans conference (where the hatchets wielded with such gusto in the 
context of the EU Constitutional Treaty referendum campaign were ceremonially buried) in not coming to an accommodation with the ligne majoritaire. His strained relations with François Hollande were exposed when Hollande went off message to promise tax rises for higher earners on his partner's behalf. Royal had not approved this, and Montebourg ‘joked’ live on prime time television that Ségolène Royal’s biggest problem in the campaign was François Hollande.Montebourg was withdrawn from the front line, but questions about the professionalism and coherence of the Royal campaign began to loom large.Meanwhile, a series of gaffes on Royal's profile raising foreign visits generated uncertainty as to whether Royal had the diplomatic skills of a president in waiting. To name but a few, whilst sharing a platform in Lebanon with a Hezbollah representative who equated Israel with Nazi Germany, she did not dissent, and later claimed (unconvincingly) not to have heard the remark. In Canada, she enraged the Prime Minister by fanning the flames of Québécois secessionism. Royal made a number of other perhaps injudicious interventions, such as the praise she volunteered in China for the speed of the justice system, and her repeated calls for Iran to be denied civil nuclear technology—a more neo-conservative stance than that of George W. Bush!

The long-awaited Presidential Pact was finally launched in February. Whilst its form reflected the extraordinary modus operandi that characterised its formulation, its policy themes were surprisingly similar to previous socialist programmes. It was received as wide-ranging and ambitious, but bereft of policy detail. On France’s growing public debt problem, for example, Royal's one-line solution involves 'more efficient public expenditure', so that 'every Euro spent must be spent usefully'. No further precision is offered. The Pact assumes that strong economic growth (achieved through under-specified 'structural reforms' such as investment in research and development) will follow her victory, and this will restore the public finances. On the back of the very public tax disagreement with Hollande, the programme launch also saw the resignation of the Royal campaign's economic adviser, Eric Besson. At root were doubts about the costing of the programme, and the Royal team's claim that it could be fully financed without tax rises.

The combination of its breadth of scope, and its vagueness made it difficult to distil the essence of the Pact in media campaigning. Whilst Sarkozy's campaign hammered away on the immigration issue, Royal's struggled to settle on consistent, clear themes. This, combined with nagging doubts about the Presidential Pact's 
feasibility did little to restore Royal's popularity. Her polling percentages declined from the mid-thirties to the mid-twenties between December 2006 and February 2007. Out of something approaching desperation, Royal drastically reorganised her campaign team, bringing back all those PS éléphants she had spent 2006 snubbing. Whilst this was testament to the strength and value of partisan resources in presidential campaigning, it did little to validate the sense of renewal that she claimed for her campaign. Her campaign platforms were now peopled with the same greyhaired men who had, for 30 years, populated the campaigning platforms of Socialist presidential candidates. So much for the 'democratic revolution' Within a week, the 'hokey cokey’ Royal was leading with the party elite took another turn. They were sidelined once more as she re-emphasised the 'personal', 'independent' (read nonpartisan) character of her candidacy.

\section{Conclusion}

At the time of writing (after the first round) the citizen's jury is still out as to whether Royal really could represent a 'democratic revolution' in France, but her campaign (and first round score) give limited grounds for optimism. Ségolène Royal's earlier poll popularity was widely interpreted as a vote in favour of political renewal in France. Organisationally, her new grass-roots political movement, professing to embody a new style of participatory, down-to-earth politics was eclipsed by the PS and its éléphants. Royal's distance from the party's past and its practices varied almost from week to week of her flagging campaign. Such vacillation over the party's centrality (or not) to her campaign did little to allay concerns about the inconsistency of the Royal campaign and the lack of an identifiable core to her political project.

Ideologically, her novel political language and style combines with a complex blend of egalitarianism and authoritarianism that treads novel ground for French politics. Yet the intriguing elements of her political vision have struggled to coalesce into a coherent and credible presidential programme. She claims to incarnate a new politics of the left, leaving behind the empty promises of the bold rhetorical flourishes of earlier Socialist campaigns. Yet she has replaced the traditional mode of abstract political rhetoric in France with her own brand of ambiguous, empty phraseology. Front National Vice President Marine Le Pen’s riposte to Royal's vague, expansive programme of dubious feasibility was that it would require her to secure the services of Merlin the wizard as Prime Minister. 
A record first round turnout (85 per cent) indicated the French electorate's unprecedented mobilisation for this election, signifying as it does a generational change in France's leaders. The legacy of 21 April 2002 also doubtless played its role. With the desire to avoid another 'earthquake,' a massive 'useful vote' for the mainstream candidates saw Le Pen's score plummet to 10.5 per cent. ${ }^{10}$ Indeed, Le Pen was for once over rather than underestimated in the polls, ${ }^{11}$ raising questions about French pollsters' 'adjustment process’ massaging (upwards) Le Pen’s scores assuming that many respondents do not reveal their true intentions.

PS pollster Gérard Le Gall’s warning in early March that Royal may not reach the second round ${ }^{12}$ was, as it turned out, overly pessimistic. Yet Royal's thoroughly respectable 25.8 per cent was disconcertingly adrift from Sarkozy's very strong score (31.1 per cent). Her hesitant, uninspiring speech on the night of the first round betrayed her camp's disappointment, and anxiety about this first round deficit vis-àvis Sarkozy. Early second round polls predicting Sarkozy at 53.5 per cent, Royal at 46.5 per cent cannot have helped.

Royal reduced the problem of left fragmentation with the incorporation of the Parti Radical de Gauche's Christiane Taubira and Mouvement des Citoyen's JeanPierre Chevenement (both of whom stood against Jospin in the 2002 first round) in her campaign team. But the first round results confirm the virtual disappearance of the former 'gauche plurielle' coalition partners of 1997, heralding a strategic crisis for French Socialism. Its allies are marginal electoral forces (1.6 per cent for the Verts and a derisory 1.9 per cent for the Parti communist français). This erosion of the Left is a serious source of electoral weakness, and sounds the death knell of the traditional Socialist electoral strategy of rassemblement à gauche. The combined score of the six candidates to the Left of Royal scarcely reached 10 per cent, with Olivier Besancenot's 4.1 per cent for the Ligue communiste révolutionnaire the only 'respectable' score. Indeed, questions may be asked about the wisdom of Royal's courting this leftist vote with economic and social policy promises during 2007.

Royal hastily began the work of constructing an anti-Sarkozy front. Given their marginality, the 'left of the left's rallying to this cause brought cold comfort. The success of this enterprise hinges on the seduction of Bayrou's surprisingly large (18.5 per cent) centrist electorate on a large scale. Former Socialist Prime Minister Michel Rocard and former Socialist minister Bernard Kouchner reiterated calls for an alliance between left and centre on the night of the first round. Were it to succeed, this would 
add substance (perhaps not that initially intended) to Royal's claims to incarnate political renewal in France. Yet this has been attempted unsuccessfully by Socialists before (by Rocard in 1988, and again in 1994, by Jospin in the first round campaign of 2002). Royal can only hope that her novelty, gender and unusual campaign themes, generating support from atypical sections of the electorate, may provide a more conducive environment this time. She faces an uphill struggle in the second round against an accomplished, effective campaigner and a formidable, driven adversary.

\section{Notes}

1 Baromètre Politique Français, Deuxième Vague-Automne 2006, CEVIPOF_-Ministère de l’Intérieur, 2006-7; http://www.cevipof.mshparis.fr/bpf/barometre/vague2/BPFV2_R15579_Ensemble.pdf, p. 44.

2 Jean Charlot , 'Le Président et le parti majoritaire,' Revue Politique et Parlementaire, No. 905, 1983, pp. 27-42, at p. 28. See also Ben Clift, French Socialism in a Global Era, London, Continuum, 2003, pp. 57-104; Alistair Cole, 'The Presidential Party and the Fifth Republic’ West European Politics, Volume 16 1993, pp. 49-66; John Gaffney, 'The emergence of a presidentialised party: the Socialist Party,' in French Political Parties in Transition, ed. A Cole, Aldershot, Dartmouth, 1990, pp. 61-90; Jean-Louis Thiebault, 'Party leadership selection in France', European Journal of Political Research, Volume 24, 1993, pp. 277-93.

3 'François Hollande: “Une candidature s’est incontestablement installée”, Le Monde, 3 October 2006. 4 'Ségolène Royal invite les Français à définir eux-mêmes l'“ordre juste”, , Le Monde, 21 November 2006; and 'Ségolène Royal veut impliquer les élus locaux dans sa campagne’, Le Monde, 22 November 2006.

5 'Les principaux points de la déclaration de Ségolène Royal’, Le Monde, 26 November 2006.

6 'François Hollande: “Ce sont tous les socialistes qui ont gagné”, Le Monde, 17 November 2006.

7 'La réaction de Ségolène Royal', Le Monde, 17 November 2006.

8 'Les Français et les 35h’, a SOFRES poll for CEVIPOF, Sciences-Po Paris, April 2005. I would like to thank Sylvain Brouard of CEVIPOF for kindly sharing the results of this poll with me.

9 'I'm not a Blair. I'm a real socialist says Royal', The Times, 13 October 2006.

${ }^{10}$ For all results see http://www.interieur.gouv.fr/sections/a_votre_service/resultatselections/PR2007/FE.html

11 'Les intentions de vote pour Jean-Marie Le Pen en 2007 sont plus élevées qu'en 2002', Le Monde 9 March 2007, see also CSA Le Monde poll, ‘Attitude des Français à l’égard de la présence de JeanMarie Le Pen à la présidentielle et intentions de vote selon sa presence ou non', November 2006; http://medias.lemonde.fr/mmpub/edt/doc/20061124/838209_sondagecsa-lepen061124.pdf

12 ‘Le “M. Sondages” du PS s'inquiète: “Il y a un risque pour Ségolène au 1er tour”, Le Monde 8 March 2007. 